\title{
Crescent and Electoral Strength: Islamic Party Portrait of Reform Era In Indonesia
}

\author{
LILI ROMLI1
}

\begin{abstract}
The establishment of Islamic political parties in the reform era in Indonesia after the fall of Suharto (1998), considered as resurgence of political stream. There are several factors that led to the revival of Islamic parties after the New Order, the theological factor, historical, sociological, and reform factor. The presence of Islamic political parties after the New Order was apparently diverse and fragmented. In the political elite of Islam itself in establishing a political party based on Islam and there is also based on nationality, and in establishing political party was using substantially approach and there is also that use formalistic approach. In the reform era elections, political Islam has failed, in which Islamic parties do not receive optimal support from voters Islam. The failure of Islamic parties in election of reform era is caused of factor among Muslims has been change the orientation of political views. Islamic parties in the reform era stuck in a political myth quantity, and Islamic parties are also fragmented and fractured in to small forces.
\end{abstract}

Keywords: Election, Islamic political party, Indonesian Politics, Political Science

Journey of Islamic parties in Indonesia after independence began with Masyumi establishment. Two major Islamic organizations, Nahdhatul Ulama (NU) and Muhammadiyah are the pioneer of Masyumi establishment, November 1945. It was agreed that Masjumi as the sole forum for channeling the aspiration and struggle of Muslims in Indonesia. But in the way, one by one Masyumi supporting element began to leave and set up his own political party. July 1947, PSII (Partai Syarikat Islam Indonesia) left Masyumi and redeclared as an independent political party. Traces of PSII was followed by NU. In 1952, NU was declared out of the Masjumi and proclaimed as a political party as NU Party. In addition, there was other Islamic party dominate in Sumatra; Perti (Pergerakan Tarbiyah Islamiyah).

During parliamentary democracy, the role of Islamic parties coloring democracy and governance. Islamic parties are indispensable part in the formation of the cabinet. Each cabinet formation, the Islamic parties are key element in forming the coalition government. The 1955 election, which is the first election after independence of Indonesia, six Islamic parties were contestant, Masyumi, NU, PSII, Perti, Partai Pesartuan Tharikah Islam (PPTI), and AKUI. 1955 Election result showed Islamic parties did not obtain majority vote. Masyumi gained 20.9\% vote, NU gained $18.4 \%$ vote, PSII gained $2.0 \%$ vote, Perti gained $1.3 \%$ vote, PPTI and AKUI each gained $0.2 \%$ vote (Feith 1957: 58). Entered a period of Guided Democracy, Islamic parties are forced to support the Nasakom ideology. As a result, Islamic parties split become two, a group that supports the ideology Nasakom that is represented by NU and those who oppose, that is represented by Masyumi. NU entered the circle of power for supporting the ideology Nasakom Soekarno, while

${ }^{1}$ Lili Romli, Researcher at Center for Political Studies, Indonesian Institute of Sciences (LIPI) and Lecturer of Political Science at Graduate School of National University, Jl. Sawo Manila, Pejaten, Ps. Minggu Jakarta 12520 JAKARTA, Indonesia, Email: liliromli@yahoo.com. 
Masyumi, for refusing, then dissolved by Sukarno in 1960. With the dissolution of the political power of Islam, Masyumi practically excluded from the arena of power. For, although NU is in the circle of power, it has no role and no power. Observers assume that NU accept Nasakom ideology as opportunistic political stance (Deliar Noer 1987). When the New Order appeared holding the reins of power, the Muslims have great expectations, which will appear back Masyumi. The hope turned out it was just a hope. Because the regime did not allow Masjumi back as a political party. Instead, the regime allowed the establishment of Parmusi. The establishment is also with a note: figures exMasyumi prohibited from engaging in the management of the party (Ali \& Bakhtiar 1986: 108). Government action did not stop there. For reason of political stability as a prerequisite of economic development, the New Order then restructure the party system. With this policy, the Islamic parties (Persatuan Muslimin Indonesia or Parmusi, NU, PSII and Perti) and other parties (Partai Nasional Indonesia or PNI, Partai Katolik, Partai Kristen Indonesia or Parkindo, and Ikatan Pendukung Kemederkaan Indonesia or IPKI) forced to perform fusion. Four Islamic parties, Parmusi, NU, PSII and Perti join in PPP (United Development Party). Thus, PPP is the only Muslim political power.

The process of marginalization of New Order regime against political Islam apparently continues, by issued "deideologizing" policy. In this policy, the political parties are not allowed to use other principle than the principle of Pancasila. As a result of the policy, the political parties have no other choice. PPP Finally, as the last bastion of Muslim political power, removed and replaced Islamic principles to be Pancasila principles. Likewise with the symbol of "Kaaba" was changed to "Star", in 1985. Star emblem is a symbol of Pancacila first precepts contained in the "body Garuda Pancasila". Substitution PPP ideology and symbol, according to Nasir Tamara, a process of political "deislamization" and "depoliticization" of Islam. After the PPP as the only representation of political Islam forces have stripped the principles of Islam and accepted the principle of Pancasila, historian Taufik Abdullah said that the PPP accept Pancasila as the principle that it is "last page of political Islam in Indonesia" (Tamara 1988). Post-New Order Indonesia, due to the reform movement spearheaded by Santri, has been an explosion of political participation. The explosion of political participation was not only affects the future of grass roots but also attacked the political elite. As an embodiment of the explosion of political participation, political elites competing to set up or revive political parties, including the establishment of Islamic parties. In this brief article, try to explain the phenomenon of the establishment of Islamic parties in Indonesia, the reform era and how its strength in elections.

\section{Revival of Islamic Political Party}

The establishment of Islamic political parties in the reform era in Indonesia after the fall of Suharto (1998), considered as resurgence of political stream. This is because in the past, the New Order did "dealirinisasi" (removal of various political ideology) policy with series of policies such as: the "depoliticization" of the masses, floating mass, and "deideologizing" by imposing Pancasila as the sole basis. After the fall of the New Order, political affiliations, especially religious, revival with a form of the establishment Islamic political parties.

To understand the revival of Islamic political parties Indonesia's reform era can be approximated by the political stream. In Indonesia, political stream is introduced by Clifford Geertz, based on his research results in Mojokuto. In his book Religion of Java, he developed into a religious social grouping schismatic ideology socio-cultural and politic. Based on that, Geertz then developed variants Islamic community in Java over three variants, namely abangan, santri, and the aristocracy. The three variants represent different cultures. Abangan represent animistic culture and syncretism, santri focus on aspects of orthodox Islam, and the aristocracy emphasize aspects of Hindu-Buddhist (Abdullah 1987: 2). Geertz classification was criticized by experts, including W. Harsya Bachtiar. According to him, the classification society Geertz on Javanese Islam on three 
variants have no loyalty principle. Varian abangan and santri refers to the understanding of religion, while the aristocracy refers to social status. Thus the term aristocracy is not the same category with abangan and santri. Because there is aristocracy who obey religion, so he is called the santri. And there is aristocracy who does not adhere to religion, as he is called abangan (Bachtiar 1981: 525).

Santri-abangan dichotomy is expressed well by Robert R. Jay. In his writing : "Religion and Politics in Central Java Rural" (Jay 1963), Jay describes the relationship between Islam and Javaism schismatic, which later evolved beyond the area of religious confrontation and entered politics. Historically, according to Jay, the emergence of santri-abangan begins on Islamization in Java at the time of the Mataram kingdom. At that time, Islam was accepted as a religion, but it has been "domesticated or harmonized" with the aristocratic class tastes. The presence of Islam abangan and santri due process of Islamization in Java running uneven. There are areas of intensive experience in the process of Islamization of boarding center, forming a group of orthodox Islam. The regions are low-intensity Islamization and far from the centers of Islamic boarding schools then formed abangan (Dhofier 1978: 65). Dichotomy of santri-abangan went beyond the religious. They have different political orientations, which then led to dispute and conflict in the form of political, ideological, and class. Dispute mainly occurs in the context of the relation between religion and state. According to Victor Tanja, abangan group support idea of a total separation of religion from politic (Tanja 1982: 23). Instead of the santri argued that religion and politic should be united. In the political field, the abangan are followers of the secular nationalists and even communist. Their political orientation channeled through the secular parties, such as the Indonesian National Party (PNI) and Communist Party of Indonesia (PKI). While the santri are supporters of Islamic parties, Masyumi and NU.

According to Donald K. Emmerson, although the followers of Islam in Indonesia is majority, santri political cultural is minority. While abangan political culture is the majority. Political elite abangan more dominant in comparison with the political elite santri (Emmerson 1976: 28). The role of the dominant political elite abangan can be seen in the bureaucracy and the legislature. From colonial times, the political elite abangan more dominant than the political elite santri. Differences between groups abangan political orientation and santri are then reflected in the state debate in the Constituent Assembly. The first group, a strong supporter of the state Pancasila, and therefore rejects the basic Islamic state. The second group is a supporter of the state of Islam, and therefore rejects the state Pancasila.

Thus, in terms of the political culture, the problems faced is the creation of a meeting point between the political elite santri and the political elite abangan. Two forms of political culture are competing with each other so does not reach a consensus (Feith 1968: 30-31). According Kuntowijoyo, santri and abangan cultural dichotomy is now over. The process of change begins dichotomy abangan and santri since the introduction of religious education in public schools. Thus, practically abangan children get the same basis of religious education. Meanwhile, the development of public education in Islamic boarding schools have eliminated the cultural exclusivism among santri (Kuntowijoyo 1998). I would argue that the changes are merely sociological. Sociologically convergence has occurred between abangan and santri. However, politically and ideologically, I think no change significantly. Despite, abangan who being santri, their political orientation and ideology has not changed. They still support the ideas of secularism in the political and religious life.

Th. Sumartana (1998) said some things that lead to the emergence of political parties based on religion. First, because religion itself has theological support to achieve the goals based on religious ideas believed. Second, because of the political ties of the citizens led to religion as a factor binding to support the leader of the religious group. Third, because religious people are feeling 
more comfortable with the political leaders who were born from their own community and disbelief when politics dominated by other religious groups.

There are several factors that led to the revival of Islamic parties after the New Order, the theological factor, historical, sociological, and reform factor. First, the theological. Unlike Christianity in looking at the relationship between religion and the state, which the two are separate areas. Religion is a private matter in a relationship with God. While the state is a public matter that should not be interfered by religious issues. There are three views of the relationship between religion and the state, namely: integrated, symbiotic mutualism and secularists. The existence or the presence of Islamic political parties associated with the first view, the unity of religion and state (integrated). In this view, religion is something that is Integrated, which are inseparably connected. Islam is din wa daulah, as well as the state religion or politics. Second, sociological factor. Islam is the majority religion in Indonesia. The adherent is about $90 \%$ of the total population of Indonesia. With the majority, it is appropriate to effort the distribution of political aspiration accordance with Islamic values and struggle. The existence of Islamic political parties regarded as the aspiration of the Islamic struggle organization. Thus, the establishment of the Islamic political party is a necessity that cannot be circumvented: sociologically Muslims in Indonesia are majority adherent, and they will feel comfortable and safe when the distribution of their political aspiration is through the Islamic political party. This sociological context seems to be used by Islamic political elites to establish an Islamic political party. With the majority of Muslims would get the support of Muslims. The existence of Islamic political parties will automatically be backed up by Muslims. Moreover, coupled with a theological perspective, where the need for a means of struggle to realize the aspirations of Islam so that the sociological and theological factors met: complement and support one another. Third, historical factor. In the history of Islam in Indonesia is a force that was instrumental in the fight against the colonialist. Islam in those days was one of the frontline in ousting the colonialist. In order to oust the colonialist was necessary to have an organization as unifying aspiration and goal. Then it's recorded, the establishment of Sarekat Islam (SI), as the first organization of political power that has the most members among the other movement organizations. When Indonesia became independent, the establishment of Masyumi becomes a dealer Muslim aspirations. Followed by the establishment of other Islamic parties, i.e. PSII, NU and Perti. Fourth, reform factor. The reform that is initiated by santri in toppling the regime spawn an era of freedom. In this era, any group or groups are given the opportunity to channel or form political party in accordance with principles and its political aspirations. This opportunity seems is not wasted by the political elites, including the Islamic political elites to form political parties. As discussed earlier, the Islamic political parties established like mushrooms in rainy season.

The presence of Islamic political parties after the New Order was apparently diverse and fragmented. In fact not only that, in the political elite of Islam itself in establishing a political party based on Islam and there is also based on nationality. Islamic political elites in establishing political party were using substantially approach and there is also that use formalistic approach. The first approach, substantially, in founding a political party, which although base of Muslims, but the ideology based on nationalism and plural. Political parties such as National Mandate Party (PAN) and the National Awakening Party (PKB), for example, are models of substantially approach. While the latter approach, formalistic, establish political parties by using symbol, names, and principles of Islam. Islamic elites formalistic approach, in establishing an Islamic party is not all based on the principles of Islam, but there is a political party based on the principles of Islam and Pancasila, and political party based on the principles of Pancasila. Thus, viewed from the usage of the principle there are three groups of Islamic parties, namely: Islamic party based on Islam; Islamic Party based on Islam and Pancasila, and; Islamic party based on Pancasila. List the three types of parties can be seen in the Table 1: 
Table 1: Islamic Parties Based on Islam

\begin{tabular}{|c|c|c|c|}
\hline No. & Party & Ideology & Chairman \\
\hline $\begin{array}{l}1 \\
2 \\
3 \\
4 \\
5 \\
6 \\
7 \\
8 \\
9 \\
10 \\
11\end{array}$ & $\begin{array}{l}\text { Partai Persatuan Pembanguan (PPP) } \\
\text { Partai Bulan Bintang (PBB) } \\
\text { Partai Keadilan (PK) } \\
\text { Partai Umat Islam (PUI) } \\
\text { Partai Syarikat Islam Indonesia (PSII) } \\
\text { Partai Syarikat Islam Indonesia (PSII) } 1905 \\
\text { Partai Ka'bah } \\
\text { Partai Dua Syahadat (PDS) } \\
\text { Partai Daulat Umat (PDU) } \\
\text { Partai Demokrasi Islam Republik Indonesia (PADRI) } \\
\text { Partai Kebangkitan Nasional Ulama (PKNU) }\end{array}$ & $\begin{array}{l}\text { Islam } \\
\text { Islam } \\
\text { Islam } \\
\text { Islam } \\
\text { Islam } \\
\text { Islam } \\
\text { Islam } \\
\text { Islam } \\
\text { Islam } \\
\text { Islam } \\
\text { Islam }\end{array}$ & $\begin{array}{l}\text { Hamzah Haz } \\
\text { Yusril Ihza Mahendra } \\
\text { Hidayat Nur Wahid } \\
\text { Deliar Noer } \\
\text { Taufik Tjokroaminoto } \\
\text { Ohan Sudjana } \\
\text { Achmad Suhaemi } \\
\text { KH. Mukarta } \\
\text { Bambang Widyatomo } \\
\text { Heri Iskandrsyah } \\
\text { R.Idris Tamami }\end{array}$ \\
\hline $\begin{array}{l}12 \\
13 \\
14 \\
15 \\
16 \\
17 \\
18 \\
19\end{array}$ & $\begin{array}{l}\text { Partai Abul Yatama (PAY) } \\
\text { Partai Masyumi Baru (PMB) } \\
\text { Partai Nahdlatul Ummat (PNU) } \\
\text { Partai Kebangkutan Umat (PKU) } \\
\text { Partai Pengamal Thariqat Islam } \\
\text { Partai Persatuan Thariqat Islam } \\
\text { Partai Kebangkitan Muslim Indonesia (Partai KAMI) } \\
\text { Partai Kebangkitan Kaum Ahlus Sunah Wal Jama'ah } \\
\text { (PAKKAM) } \\
\text { Partai Era Reformasi Tarbiyah Islamiyah (PERTI) }\end{array}$ & $\begin{array}{l}\text { Islam and Pancasila } \\
\text { Islam and Pancasila } \\
\text { Islam and Pancasila } \\
\text { Islam and Pancasila } \\
\text { Islam and Pancasila } \\
\text { Islam and Pancasila } \\
\text { Islam and Pancasila } \\
\text { Islam and Pancasila } \\
\text { Islam and Pancasila }\end{array}$ & $\begin{array}{l}\text { Rusli Bintang } \\
\text { Ridwan Saidi } \\
\text { KH. Sukron Makmun } \\
\text { KH. Yusup Hasyim } \\
\text { Masykur Loamena } \\
\text { Syech St Muchtar Doyah } \\
\text { Syamsahril } \\
\text { Sjarkawi Machudum } \\
\text { HST Sukarnotomo }\end{array}$ \\
\hline $\begin{array}{l}22 \\
23 \\
24 \\
25 \\
26 \\
27 \\
28 \\
29 \\
30\end{array}$ & $\begin{array}{l}\text { Partai Aliansi Kebangkitan Muslim Sunny (Partai } \\
\text { AKAMSI) } \\
\text { Partai Politik Tharikat Indonesia } \\
\text { Partai Solidaritas Uni Nasional Indonesia (Partai SUNI) } \\
\text { Partai Ummat Muslimin Indonesia (PUMI) } \\
\text { Partai Bhakti Muslim (PBM) } \\
\text { Partai Indonesia Baru (PIB) } \\
\text { Partai Islam Demokrat (PID) } \\
\text { Partai Islam Persatuan Indonesia (PIPI) } \\
\text { Partai Kesatuan Ummat Indonesia (PKUI) } \\
\text { Partai Persatuan Sabilillah (PPS) }\end{array}$ & $\begin{array}{l}\text { Pancasila } \\
\text { Pancasila } \\
\text { Pancasila } \\
\text { Pancasila } \\
\text { Pancasila } \\
\text { Pancasila } \\
\text { Pancasila } \\
\text { Pancasila } \\
\text { Pancasila } \\
\text { Pancasila }\end{array}$ & $\begin{array}{l}\text { KH. Sofyan Siradj } \\
\text { Rahman Sabon } \\
\text { Abu Hasan } \\
\text { KH. Anwar Junus } \\
\text { Ibnu Hasyim Lubis } \\
\text { HM. Syaiful Anwar } \\
\text { Andi Rasyid Jalil } \\
\text { HM. Dault } \\
\text { Zakiruddin } \\
\text { Herman Sastrawinata }\end{array}$ \\
\hline
\end{tabular}

\section{Islamic Political Parties and Electoral Reform Era}

One of the demands of the reform movement is the elections that are accelerated. This is because the peoples' representatives in the House/Assembly are Election 1997 result, considered illegitimate and part of the New Order regime. In addition, the 1997 election was won by Golkar that is engineered by the New Order regime that doing manipulation and intimidation. Because of that, the results of the 1997 elections are considered illegitimate. Instead it is necessary to reelection that is democratic, fair, and overflow (direct, general, free and secret). Under these conditions, the Electoral Act 1998 which came out accelerate the election. By embracing the proportional system, then set the election was held on June 6, 1999. There were 48 political parties that qualify for the 1999 elections. Of those amounts, 17 of which are Islamic political party. They are: PPP, PBB, PK, PP, PUI, PMB, PPI Masyumi, PID, PIB, PSII, PSII 1905, PNU, PKU, Partai SUNI, Partai KAMI, PAY, and PUMI. 
Election 1999 is the moment to prove whether the Islamic parties will gain the support of their constituents, i.e. Muslims reach $90 \%$ of the total population of Indonesia (120 million people). This is because in this election, battles between political forces to gain the electoral participants voice. In this context, each of the participants or contestants try to influence the election and appeal to the masses by offering programs and promises for a new post-New Order Indonesia. Generally, there are five political forces which fought in the 1999 elections, i.e. the political power of Islamic parties; the political power of parties base of Islamic mass; secular nationalist political forces; the political power of democratic socialism, and; the political power of the Christian groups. In order to deal with these forces, Islamic parties joined by doing stembuss accord (incorporation of residual vote). With stembuss accord is expected political parties votes of Islamic constituents not lost. But unfortunately, not all the Islamic parties joined in stembuss accord,only nine of the 17 parties contesting the election. The nine Islamic parties are: PPP, PBB, PK, PKU, PNU, PSII, 1905, and PPI Masyumi. The results of the 1999 elections showed the vote of Islamic parties fell away. From 17 Islamic parties, only PPP to be the top five, gaining $10.72 \%$ votes (59 seats). While most of the other Islamic parties did not gain significant vote to achieve any seats in Parliament. Crescent Star Party (PBB), which is considered as the main heir of Masyumi only won $1.9 \%$ of the vote or 13 seats, while the Party of Justice (PK) only able to collect $1.4 \%$ vote ( 7 seats). Several other Islamic parties like Nahdlatul Ummah Party (PNU), Unity Party (PP), Syarikat Islamic Party of Indonesia (PSII), Islamic Political Party of Indonesia Masyumi (PPI Masyumi), and the National Awakening Party People (PKU) only gained one seat each. A number of other Islamic parties are not able to garner support for a seat in Parliament.

Appeal of Majelis Ulama Indonesia or Indonesian Ulema Council (MUI) and Islamic elites to choose Islamic parties and should not vote for parties that non-Muslim majority figures ignored by the masses of Islam, especially Islamic mass grassroots. The enthusiasm of Islamic leaders who are very confident in the ability win a majority of the population of the country with each claim will be supported by a lot of Muslims is not proven. The Development Unity Party (PPP), for example, believes will be able to maintain the gains achieved in his vote as the 1997 elections, amounting to $22 \%$. While PK believe will be voted about 10-15\% (Umar 1999):

Table 2: Vote and Chairs Acquisition of Islamic Political Party in 1999 Elections

\begin{tabular}{|c|c|c|c|c|}
\hline No & Political Party & Vote & $\%$ & Chair \\
\hline 1 & Partai Persatuan Pembangunan (PPP) & 11.329 .905 & 10.72 & 58 \\
\hline 2 & Partai Bulan Bintang (PBR) & 2.049 .708 & 1.94 & 13 \\
\hline 3 & Partai Keadilan (PK) & 1.436 .565 & 1.36 & 7 \\
\hline 4 & Partai Nahdlatul Umat (PNU) & 679.179 & 0.64 & 5 \\
\hline 5 & Partai Persatuan (PP) & 551.028 & 0.52 & 1 \\
\hline 6 & $\begin{array}{l}\text { Partai Politik Islam Indonesia Masyumi (PPI } \\
\text { Masyumi) }\end{array}$ & 456.718 & 0.43 & 1 \\
\hline 7 & Partai Syarikat Islam Indonesia (PSII) & 375.920 & 0.36 & 1 \\
\hline 8 & Partai Kebangkitan Umat (PKU) & 300.064 & 0.28 & 1 \\
\hline 9 & Partai Kebangkitan Muslim Indonesia (KAMI) & 289.489 & 0.27 & 0 \\
\hline 10 & Partai Ummat Islam (PUI) & 269.309 & 0.25 & 0 \\
\hline 11 & Partai Abul Yatama (PAY) & 213.979 & 0.20 & 0 \\
\hline 12 & Partai Indonesia Baru (PIB) & 192.712 & 0.18 & 0 \\
\hline 13 & $\begin{array}{l}\text { Partai Solidaritas Uni Nasional Indonesia } \\
\text { (Partai SUNI) }\end{array}$ & 180.167 & 0.17 & 0 \\
\hline 14 & PSII 1905 & 152.820 & 0.14 & 0 \\
\hline 15 & Partai Masyumi Baru (PMB) & 152.589 & 0.14 & 0 \\
\hline 16 & Partai Islam Demokrat (PID) & 62.901 & 0.06 & 0 \\
\hline 17 & Partai Ummat Muslimin Indonesia (PUMI) & 49.839 & 0.05 & 0 \\
\hline
\end{tabular}


As shown in the table above, the majority of Islamic parties failed. Tally support of Islamic parties is very little. Thus, the claims raised by the elite that Islamic parties will be supported by the people just a figment. PKB, as a nationalist-religious parties, and PAN as a pluralist party, each gaining $12.6 \%$ votes and $7.1 \%$. Actually winning parties had been previously suspected. Instead pluralist secular parties much popular support. PDI-P as the secular party came out as the winner with $33.8 \%$ gaining votes (153 seats), followed by the Golkar Party get votes $22.5 \%$ (120 seats) (Kazhim et al. 1999). In facing the 2004 elections, which is Indonesia's second election after the reform, not all Islamic political parties could be a contestant. This happens because most Islamic parties did not pass verification as electoral participants. Some Islamic parties into electoral participants were forced to change the name because of the 1999 election does not pass electoral threshold, include the Justice Party (PK) turns into the Wellfare \& Justice Party (PKS). Unless the PKS, the results of the 2004 elections, both parties are Muslim and Islamic mass-based the vote dropped. In fact, the PBB passes in the 1999 election threshold (ET). The National Mandate Party (PAN), which despite its chairperson has been working hard and sweaty does not seem to affect anything. Instead of going up the vote, it was drastic diminution of 6.4\% (the 1999 elections, gained 7.1\%). The decline of PAN is related to the inconsistency that is exhibited by Amien Rais. As a reformist, he is often inconsistent in statement, for example, in terms of the idea of a federal state and his attitude towards the military leadership. In addition, Amien Rais is known by people, like talk a lot, one thing that is not liked by the people of Indonesia who psychological likes silence and a lot of work. Another factor is something that is considered wrong by the masses when he dropped Gus Dur president, while he who carries Gus Dur to become president in an effort to dead lock between Megawati or BJ. Habibie as president. The PPP and The PBB also suffered the same. Two Islamic parties that carry Islamic law seems less enthused by masses of Islam itself plus the issue of internal conflict that gave birth some new political parties from both parties. As a result of this conflict, born from the "womb" of PPP, Reform PPP and PBR (Reform Star Party or Partai Bintang Reformasi) and the Reform of the PBB was born Partai Al-Islam Sejahtera (PAS) and Partai Islam Indonesia (PII). Suspected, the supporters of the two parties switched to PKS, which was considered quite consistent and clean as the Islamic party. PKS gaining (7.34\%) votes due to the hard work has done. Using dual tactics, on the one hand as a party that carries Islam and the other with alignment program to the people, honest, clean, and care that is demonstrated through concrete actions, which is not only promises, ultimately foster sympathy and support of the masses to pick PKS. Masses that support PKS are those that need party actually works, not only selling promises. The issues raised by the PKS are anti corruption, rule of law, anti rotten politicians, touching the hearts of people so that they decided to throw in the PKS:

Table 3: Acquisition of Islamic Political Party and Based Islamic Mass Election Results 1999, 2004 and 2009

\begin{tabular}{|clrrr}
\hline No & \multicolumn{1}{c}{ Name of Party } & 1999 Election & 2004 Election & 2009 Election \\
\hline $\mathbf{1}$ & Partai Keadilan Sejahtera (PKS) & $1.4 \%$ & $7.34 \%$ & $7.88 \%$ \\
$\mathbf{2}$ & Partai Amanat Nasional (PAN) & $7.1 \%$ & $6.44 \%$ & $6.01 \%$ \\
$\mathbf{3}$ & Partai Persatuan Pembangunan (PPP) & $10.7 \%$ & $8.15 \%$ & $5.32 \%$ \\
$\mathbf{4}$ & Partai Kebangkitan Bangsa (PKB) & $12.6 \%$ & $10.57 \%$ & $4.94 \%$ \\
$\mathbf{5}$ & Partai Bulan Bintang (PBB) & $1.94 \%$ & $2.62 \%$ & $1.79 \%$ \\
$\mathbf{6}$ & Partai Bintang Reformasi (PBR) & - & $2.44 \%$ & $1.21 \%$ \\
$\mathbf{7}$ & Partai Persatuan Nahdlatul Ummah & $0.64 \%$ & $0.79 \%$ & $0.14 \%$ \\
$\mathbf{8}$ & Indonesia (PPNUI) & & \\
& Partai Kebangkitan Nasional Ulama & & & $1.47 \%$ \\
$\mathbf{9}$ & Parta) Matahari Bangsa (PMB) & & \\
\hline
\end{tabular}




\section{Declination of Electoral Strength of Islamic Party in the 2009 Election}

In facing the 2009 election, it predicts a slowdown in gaining votes. Indo Barometer, for example, in a survey conducted in June 2008 is predicted the acquisition of Islamic Party is relatively small. Based on the survey, the acquisition of PKS at the position $7.2 \%$, while the PPP is at $2.3 \%$ position. A survey conducted by the Indonesian Survey Institute (LSI) on February 8 to February 18, 2009, also showed that the number of Islamic party vote is predicted to decline in the 2009 election. In this context, Bachtiar Effendy said that Islamic parties can not appear as the ruling party like a secular-based parties such as Golkar Party, Indonesian Democratic Party of Struggle (PDIP), or the Democratic Party (PD). Because, he said, Islam political party area is limited. Islamic parties often bring old issues, such as the application of the syariat, the establishment of an Islamic state, and the president of the Islamic religion. He further said that after the 1955 election, support of Islamic parties continue to decline (Hasil Survei 2006). The results of the 2009 election shows that the predictions of the pollsters are not much different. Islamic parties remain middle party and decreasing. As shown in the table above, except for the PKS, all Islamic political parties and Islamic mass-based decline. Even five political parties do not qualify for Parliamentary Threshold (PT) 2,5\%, ie: Crescent Star Party (PBB), Reform Star Party (PBR), Ulema National Awakening Party (PKNU), National Sun Party (PMB), and Nahdatul Ummah Unity Party of Indonesia (PPNUI).

PPP as old party, in the 2009 election was not able to maintain its vote. PPP acquisition has declined significantly, from $8.15 \%$ in the 2004 election to $5.32 \%$ in the 2009 election. Thus, it has decreased by about three percent of the 2004 election. The decline of PPP is because this New Order legacy Party is often plagued by internal conflict and a lack of decent sales figures. Although there are two PPP cadres who sat in the cabinet, ie Bachtiar Hasyah as Social Minister and Surya Dharma Ali as Minister of Cooperatives and UKM (Small and medium businesses), seem could not be magnetised to collect support. Instead to raise PPP, both of them seem likely "busy" feuding and conflict. PBB got the vote in the 2004 election around 2.62\%, in the 2009 election has decreased dramatically, reaching only $1.79 \%$. Although PBB is relatively free of conflict, it seems that after the death of Yusril Ihza Mahendra who no longer serves as Chairman of PBB and was replaced by MS Kaban, PBB does not have an icon and prestige. PBB tends to sink into the political map along with the Yusril resignation of Justice Minister. By not passing in the House, observers predict could be Masyumi "dynasty" will be immersed in national politics. The same fate also experienced by PBR that reach $1.21 \%$. The party that was born out of PPP internal conflict, in the 2004 elections with $\mathrm{KH}$ Zaenuddin MZ as an icon, the same fate with the PBB, which is equally qualified PT. After the death of a million clerics Ummah, PBR seems no longer have a central figure that is worth selling, so degraded support. Conflict factor in PBR with release some of the PBR elite like Zaenal Maarif and Kh. Zaenudijn MZ contributed to deflate the PBR vote. Despite the efforts made by the leader of PBR, Bursah Zarnubi, by recruiting young people and among activists apparently still not able to achieve significant mass support. PKNU is a new Islamic party product of PKB internal conflict. Under the command of Khaerul Anam and "help birth" by Kyai Langitan, less Nahdiyin give support to PKNU. Rather than beat PKB, PKNU also not escaped PT. It seems clerics charismatic experiencing "crisis effect"; with low levels of vote support obtained by PKNU. Whereas in the body PKNU not a few clerics who enter into it. The same fate also experienced by PMB, which did not qualify for PT. Despite carrying Din Syamsuddin as a presidential candidate and claims as the biological child of Muhammadiyah, still he was not able to attract massive constituents of Muhammadiyah. Muhammadiyah mass seems most still support PAN. This is because Amin Rais is still behind the PAN.

Vote declining occurs not only to Islamic parties, Parties with Islam base also decreased, namely PAN and PKB. PAN in the 2004 elections gained 6.44\%, in the 2009 election decreased to 6.01\%. Whereas to deal 2009 election, the party under the leadership Sutrisno Bachir nominating

https://doi.org/10.24035/ijit.4.2013.005 
several artists as PAN candidates as vote getters and sound panners. Apparently the result was not much change. PAN leadership post Rais seems to miss the central figure as an attraction and "worth selling". PMB Founding is a factor that is also undermining vote of PAN. While PKB, after internal conflict with the establishment of PKNU and releasing of Gus Dur from PKB under the leadership of Muhaimin Iskandar, vote gaining also fells sharply, from $10.57 \%$ to $4.94 \%$. Decreased PKB vote has been predicted, because the absence of Gus Dur as PKB icon with charisma and his loyal masses, the party that was born from the womb of NU would lose the central figure which has been a magnet for PKB. Almost the same as Partai Demokrat (PD) and Partai Demokrasi Indonesia Perjuangan (PDIP), PKB is also identified with the figure, the figure of Gus Dur. So when Gus Dur leave PKB, PKB becomes unsteady, loss its loyal supporters. Islamic Party which rose its vote, though slightly from 7.34 percent to 7.88 percent is PKS. PKS voting is relatively stable, not declining, one explanatory factor is sustainable regeneration. If PKS vote in the 2004 election is from the swing voters, in the 2009 elections is majority vote comes from the PKS cadres and sympathizers of PKS. They of course still come from the mass base of Islamic parties. The phenomenon "predatorism" or "cannibalism" among Islamic parties in this case is still relevant.

It can be concluded that, the failure of Islamic parties in election of reform era is caused by factor, first, among Muslims has been changing the orientation of political views. As a result of the government modernization and reform movement spearheaded by Nurcholis Madjid, impacts to the views of Muslims who are no longer bound by the symbols of Islamization. People no longer see Islamic party as a representative to Islamization, but had seen the extent of a party to apply to the values of Islamization. So the emphasis by the people was substantial but not formalism. They do not see what the label that is used by a party but rather to see how far a party fight, for example, on democratization, human rights, transparency, and so on. Islamic parties in the reform era stuck in a political myth quantity. The view that the majority of Indonesia population is Muslims, they will choose Islamic parties. The myth is not up to the reality. The history of elections proves that Muslims support for Islamic parties is small. Reality shows that not all Muslims in Indonesia are ideological. Facts show that Muslims in Indonesia tend to be sociological. Following Geetz typology, that the Muslims of Indonesia was a devout, called the santri and there are Muslims who are less devout or nominal Muslims, called abangan. The last certainly did not vote for a party because they have viewed that religion must separate from political affairs. Deliar Noer wrote that there were four Muslim groups, namely: (1) group of people who are committed to Islam; (2) group that want to cooperate with authorities, (3) those who view Islam as "the only teaching", and (4) group that does not want to associate Islam as a religion with politics (Noer 1988). Islamic parties are also fragmented and fractured into smaller forces. As it's known in the reform era, there are 32 Islamic parties, from the amount 17 parties basses. Of course this number very much. With many of these Islamic parties confuse Muslims. In addition to the fragmentation and fracturing of the Islamic parties with the party itself weaken Islam itself as a political force.

It also can be said that the failure of Islamic parties relates to the disarticulation of Islamic political thought and practice. The practitioner or Islamic politicians have sold something that is not needed by the public. The issues thrown less striking and biting, so it does not have an attraction for the public. Modernization project of New Order government, result secular pragmatic view among Muslims. As a result of the modernization occurred transformation socio-economic, especially among the middle class or educated. They are then shifted in political orientation, which was formalistic in looking at the relationship between religion and politic to be substantialistic where Islam is quite as ethical and moral guidance in the life of the nation and the state. With the failure of Islamic parties in elections in the reform era, the question arises: how is the future of political Islam? Is it still will survive and still have the support of Muslims. It's hard to answer that question. But as a temporary response to the reality of the election results cited above in which the Islamic parties suffered a crushing defeat, it can be said that the future of political Islam in 
Indonesia is not so promising. Plummeting sound of Islamic parties or mass-based Muslims could be demonstrated that the political stream has faded, especially Islam. By decreasing Islamic parties vote in the 2009 election is a signal that the political stream is dead, as suggested by R. William Liddle and Saiful Mujani. In their study they concluded that the political stream has faded (Muhtadi 2009). However, it's not too late for the forces of political Islam taking steps toward consolidation. Division and fragmented forces of political Islam into the parties need to be addressed immediately. Among the Muslim political elites need better cooperation toward a solid strength. When the division and fragmented is not solved soon, history proves that political power is fragmented will not be effective in eliciting strength to win support from Muslims.

\section{References}

Abdullah, Taufik. 1987. Islam dan Masyarakat: Pantulan Sejarah Indonesia. Jakarta: LP3ES.

Ali, Fachryi and Bahtiar Effendy. 1986. Merambah Jalan baru Islam. Jakarta: Mizan.

Bachtiar, Harsya W. 1981. Religion of Java; Sebuah Pengantar. Dlm. Clifford Geertz. Abangan, Santri dan Priyayi dalam Masyarakat Jawa. Jakarta: Pustaka Jaya.

Al-Chaidar. 1998. Pemilu 1999: Pertarungan Ideologis Partai-partai Islam Versus Partai-partai Sekuler. Jakarta: Darul Falah.

Dhofier, Zamaksyarai. 1978. Santri-Abangan dalam Kehidupan Orang Jawa: Teropong dari Pesantren. Prisma 5.

Effendy, Bachtiar. 1988. Repolitisasi Islam: Pernahkah Islam Berhenti Berpolitik? Republika. December, 29.

Emmerson, Donald K. 1976. Indonesia's Elite: Political Culture and Cultural Politics. Ithaca and London: Cornell University.

Feith, Hebert. 1957. The Indonesian Election of 1955. Ithaca: Cornell University Press.

Feith, Herbert. 1968. The Decline of Contitutional Democracy in Indonesia. Ithaca and New York: Cornell University Press.

Feith, Herbert \& Castel, Lance. 1988. Pemikiran Politik Indonesia 1945-1965. Jakarta: LP3ES.

Gaffar, Afan. 1992. Javanese Voters. Yogyakarta : Gadjah Mada University Press.

Geertz, Clifford. 1981. Abangan, Santri and Priyayi dalam Masyarakat Jawa. Jakarta: Pustaka Jaya.

Hasil Survei: Partai Islam tak Akan Menang Pemilu, http://www.tempointeraktif. com/hg/nasional/2006/10/15/brk, 20061015-86104.

Hassan, Sahar L (ed.) . 1988. Memilih Partai Islam. Jakarta: Gema Insani Press.

Haris, Syamsuddin. 2000. Pemilu 1999 dan Format Politik Baru. Jakarta: LIP FISIP-UI-Mizan.

Jay, Robert R. 1963. Religion and Politics in Rural Central Java. New Haven: SAS Yale University.

Karim, M. Rusli. 1983. Perjalanan Partai Politik di Indonesia. Jakarta: Rajawali Press.

Karim, M. Rusli. 1999 Negara dan Peminggiran Islam Politik. Yogyakarta: Tiara Wacara.

Kazhim, Musa \& Hamzah, Alfian (ed.). 1999. 5 Partai Islam dalam Timbangan. Jakarta: Pustaka Hidayah.

Kuntowijoyo. 1998. Enam Alasan Untuk Tidak Mendirikan Parpol Islam. Republika. July, 18.

Liddle, R. William. 1988. Politics and Culture in Indonesia. Ann Arborr: Centre for Political Studies for Social Research The University of Michigan.

O’Donell \& Schmitter. 1993. Transisi Menuju Demokrasi Rangkian Kemungkinan dan Ketidakpastian. Jakarta: LP3ES.

Muhtadi, Burhanuddin. 2009. Prospek Partai-Partai Islam dalam Pemilu 2009. http://islamlib.com /id/ artikel/prospek-parta-partai-islam-dalam-pemilu-2009.

Mulkham, Abdul Munir 1994. Runtuhnya Mitos Politik Santri. Yogyakarta: Sipress.

Noer, Deliar. 1988. Islam dan Politik: Mayoritas atau Minoritas. Prisma 5.

Noer, Deliar. 1987. Partai Islam di Pentas Nasional. Jakarta: Grafitipers.

https://doi.org/10.24035/ijit.4.2013.005 
Rahardjo, M. Dawam. 1998. Partai Politik dan SARA. Media Indonesia. July, 11.

Salim, Arskal. 1999. Partai Islam dan Relasi Agama-Negara. Jakarta: JPPM.

Samson, Allan. 1978. Conceptions of Politics, Power and Ideology in Contemporary Indonesian Islam. Dlm. Karl D. Jakcson \& Lucian W Pye (eds.). Political, Power and Communications in Indonesia. Berkeley: University of California Press.

Sumartana, Th. 1998. Politik Islam dan Pluralisme Bangsa. Majalah D \& R. August, 15.

Tamara, Nasir. 1988. Sejarah Politik Islam Orde Baru. Prisma 5.

Tanja, Victor. 1982. Himpunan Mahasiswa Islam. Jakarta: Sinar Harapan.

Thohari, Hajriyanto Y. 1998. Partai Islam dan Elektoral Islam. Kompas. August, 25.

Umar Ibn Sholeh. 1999. Tujuh Mesin Pendulang Suara. Jakarta: LkiS.

Vatiokotis, P.J. 1987. Islam and The State. London: Routledge. 